(C) С.О. Бойко, 2019

УДК 616.61-006.6-06:616.146.2-005.6]-036-07

\title{
Симптоми та клінічний перебіг нирково-клітинного раку, ускладненого імплан- таційним тромбозом ниркової та нижньої порожнистої вен
}

С.О. Бойко

boiko.likar@gmail.com

Ужгородський національний університет, медичний факультет, кафедра хірургічних хвороб, Ужггород

\section{Реферат}

Вступ. Особливістю клінічного перебігу нирково-клітинного раку є його схильність до венозного поширення 3 формуванням імплантаційного тромбу у нирковій чи нижній порожнистій венах. Симптоми даного процесу чітко не описані в літературі.

Мета дослідження. На основі вивчення клінічного перебігу НКР, ускладненого імплантаційним тромбозом ниркової та нижньої порожнистої вен визначити симптоми захворювання, пов'язані з формуванням обструкції НПВ.

Матеріали та методи. Дослідження грунтується на обстеженні і хірургічному лікуванні 127 хворих на НКР,

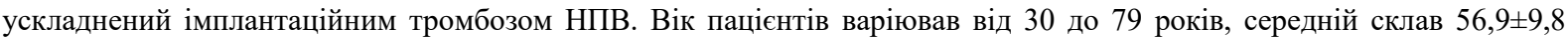
року. Чоловіків було 83 (65,4\%), жінок - 44 (34,6\%).

Результати досліджень та їх обговорення. Загальний стан пацієнтів за шкалою ECOG був таким: 0 балів виявлено у $83(65,4 \%)$ хворих, 1 бал - у $39(30,7 \%)$ і 2 бали - у $5(3,9 \%)$. Рівні поширення пухлинного тромбу по НПВ визначені за класифікацію клініки Меуо: 0 рівень мали $50(39,4 \%)$ пацієнтів, I рівень - 26 (20,5\%), II рівень - 27 (21,2\%), III рівень - 18 (14,2\%) і IV рівень - 6 (4,7\%). У 9 (7,1\%) пацієнтів, окрім пухлинного тромбозу НПВ було діагностовано флеботромбоз стегно-клубово-кавального сегменту. У 32 (25,2\%) хворих будьякі симптоми захворювання були відсутні, а виявлення пухлини нирки та пухлинного венозного тромбу було випадковою знахідкою під час ультразвукового обстеження чи комп'ютерної томографії з приводу інших захворювань. Клінічні симптоми було виявлено у 95 (74,8\%) пацієнтів. Найбільш частими симптомами були клінічні прояви місцевого поширення пухлини у вигляді болю у поперековій ділянці чи животі (44,9\%) та макрогематурії (33,9\%). Ознаки ракової інтоксикації у вигляді загальної слабкості виявлено у 22,8\% випадків. Сим птоми здавлення чи обструкції НПВ у вигляді правобічного варікоцеле було зафіксовано лише в одного $(0,8 \%)$ пацієнта. Набряк нижніх кінцівок (збільшення об'єму нижніх кінцівок при різниці окілу гомілок чи стегна більше, ніж 3 см) діагностовано у 9 (7,1\%) хворих, у 6 з яких мав місце ціаноз шкіри нижніх кінцівок. Це були пацієнти, які окрім пухлинного тромбозу НПВ мали супутню патологію у вигляді флеботромбозу стегновоклубово-кавального сегменту.

Висновки. У 25,2\% хворих НКР, ускладнений імплантаційним тромбозом ниркової та нижньої порожнистої вен, має безсимптомний перебіг і виявлення пухлини нирки та пухлинного венозного тромбу у них є випадковою знахідкою під час ультразвукового обстеження чи комп'ютерної томографії з приводу інших захворювань. У зв'язку з цим, пацієнтам з раком нирки необхідно виконувати в обов'язковому порядку ультразвукове та рентгенологічне дослідження НПВ на предмет виявлення імплантаційного тромбу. Наявність супутнього флеботромбозу стегновоклубово-кавального сегменту слід вважати не симптомом, а ускладненням імплантаційного тромбозу НПВ.

Ключові слова: нирково-клітинний рак, імплантаційний тромб, нижня порожниста вена, симптоми, клінічні ознаки.

Abstract

Symptoms and clinical course of renal cell carcinoma, complicated by implantation thrombosis of the renal vein and inferior vena cava

S.O. Boiko

Uzhhorod National University, medical faculty, department of surgical diseases, Uzhhorod

Introduction. The peculiarity of the clinical course of renal cell carcinoma is its propensity to venous distribution with the formation of a implantation thrombus in the renal vein or inferior vena cava. Symptoms of this process are not clearly described in the literature.

The aim of the study. On the basis of the study of the clinical course of RCC, which is complicated by implantation thrombosis of the renal vein and IVC, to determine the symptoms of the disease associated with the formation of obstruction of the IVC.

Results. The overall condition of patients on the ECOG scale was as follows: 0 points were found in $83(65.4 \%)$ patients, 1 in $39(30.7 \%)$ and 2 in $5(3.9 \%)$. Levels of distribution of tumorous thrombus by IVC were determined by the classification of the Meyo clinic: the zero level was 50 (39.4\%) patients, I level - 26 (20.5\%), II level - 27 (21.2\%), III level - 18 (14.2\%) and IV level - $6(4.7 \%)$. In 9 (7.1\%) patients, in addition to tumorous thrombosis IVC, phlebotrombosis of the femur, iliac veins and IVC was diagnosed. In $32(25.2 \%)$ patients, any symptoms were absent, and the detection of kidney tumors and 
tumorous venous thrombus was an accidental finding during an ultrasound examination or computer tomography for other diseases. Clinica 1 symptoms were detected in 95 (74.8\%) patients. The most common symptoms were the clinical manifestations of local tumor spread in the form of pain in the lumbar region or abdomen $(44.9 \%)$ and macrohematuria $(33.9 \%)$. Symptoms of cancer intoxication as general weakness were found in $22.8 \%$ of cases. The symptoms of compression or obstruction of the IVC in the form of right-sided varicocele were recorded in only one $(0.8 \%)$ patient. Edema of the legs (increase in the volume of the legs more than $3 \mathrm{~cm})$ was diagnosed in $9(7.1 \%)$ patients, 6 of which were cyanosis of the legs. These were patients who, in addition to tumorous thrombosis, had a concomitant pathology in the form of phlebothrombosis of the femur, iliac veins and IVC.

Conclusion. In $25.2 \%$ patients of RCC, complicated by implantation thrombosis of the renal vein and IVC has asymptomatic course and the detection of kidney tumors and tumor venous thrombus in them is a coincidence finding during an ultrasound examination or computer tomography for other diseases. In this regard, patients with renal cancer should be obliged to perform ultrasound and X-ray examination of IVC for the purpose of detecting implantation thrombus. The presence of concomitant phlebotrombosis of the of the femur, iliac veins and IVC should not be considered as a symptom, and complication of implantation thrombosis IVC.

Key words: renal cell carcinoma, implantation thrombus, inferior vena cava, symptoms, clinical feature

Вступ. Однією з особливостей клінічного перебігу нирково-клітинного раку (НКР) є його схильність до венозного поширення 3 формуванням імплантаційного тромбу в нирковій чи нижній порожнистій венах, що трапляється у 4-14\% випадків [1-5]. У зв'язку з цим, у даної когорти пацієнтів розвиваються два напрямки формування симптомів. Перший - зумовлений наявністю основної патології у вигляді пухлини нирки, яка росте. Другий - виникає внаслідок утворення тих чи інших елементів обструкції в системі нижньої порожнистої вени (НПВ), що сприяє формуванню колатерального венозного кровоплину. Загальні симптоми раку нирки є добре вивченими. До них належать такі, як класична тріада - гематурія, біль та пухлина, що пальпується і інші симптоми - анемія, втрата ваги, паранеопластичний синдром тощо [6] Симптоми гострого венозного тромбозу НПВ $€$ також добре вивченими, адже їх виникнення зумовлене раптовістю і гостротою процесу обструкції НПВ [7]. Проте імплантаційний тромб росте тривалий час і поступово формує обструкцію НПВ, у зв'язку з чим, симптоми порушення прохідності НПВ з'являються поволі, а їх висвітлення на сьогодні має дещо суперечливий характер.

Мета дослідження. На основі вивчення клінічного перебігу нирково-клітинного раку, ускладненого імплантаційним тромбозом ниркової та нижньої порожнистої вен, визначити симптоми захворювання, пов'язані з формуванням обструкції НПВ.

Матеріали та методи. Дослідження грунтується на обстеженні і хірургічному лікуванні 127 хворих на НКР, ускладнений імплантаційним тромбозом НПВ, які знаходились у Закарпатській обласній клінічній лікарні ім. А. Новака у період з 2005 по 2018 рр. Вік пацієнтів варіював від 30 до 79 років, середній склав $56,9 \pm 9,8$ року. Серед них, чоловіків було $83(65,4 \%)$, жінок - 44 (34,6\%).

Діагностичний алгоритм складався 3 загальноприйнятих в онкоурологічній практиці клінічних, лабораторних, променевих та гістологічних методів, згідно 3 рекомендаціями Свропейської асоціації урологів. Обов'язковим було застосування ультразвукового обстеження із застосуванням доплерографії, мультиспіральної комп'ютерної чи магніто-резонансної томографії 3 контрастним підсиленням, при необхідності у деяких пацієнтів виконувалась ілеокаваграфія. Загальний стан пацієнтів оцінювали за Шкалою ECOG (Eastern Cooperative Oncology Group - Cxiдна багатоцентрова група дослідження раку, США) у балах від 0 до 4.

Для визначення рівня поширення пухлинного тромбу по НПВ використовували класифікацію клініки Меуо [1] і при цьому відмічали бік ураженої пухлиною нирки.

Клініко-анатомічне стадіювання НКР проводили згідно 3 класифікацією TNM Міжнародного протиракового союзу (UICC) 2002 року.

Усі пацієнти були прооперовані з лапаротомного доступу. Під час операції використовували загальнохірургічні та судинні інструменти. Методи допоміжного і штучного кровообігу, що включають кардіопульмонарне шунтування, зупинку циркуляції і системну гіпотермію не використовували.

Результати досліджень та їх обговорення. Оцінка загального стану пацієнтів за шкалою ECOG продемонструвала, що 0 балів виявлено у $83(65,4 \%)$ хворих, 1 бал - у $39(30,7 \%)$ і 2 бали - у 5 (3,9\%). У нашому дослідженні не було пацієнтів, у яких бал за шкалою ECOG був рівний чи перевищував 3. Таким чином, усі пацієнти перебували в задовільному стані і більше $50 \%$ денного часу були активними.

Усі пацієнти мали рак нирки в стадії $\mathrm{T}_{3-4} \mathrm{~N}_{0-2} \mathrm{M}_{0-1}$ ускладнений пухлинною венозною інвазією. Стадію $\mathrm{T}_{3 \mathrm{a}}$ діагностовано у $49(38,6 \%)$ хворих, $\mathrm{T}_{3 \mathrm{~b}}-\mathrm{y}$ $67(52,8 \%), \mathrm{T}_{3 \mathrm{c}}-\mathrm{y} 5(3,9 \%), \mathrm{T}_{4}-$ у $6(4,7 \%)$. У 8 $(6,3 \%)$ пацієнтів на момент поступлення в клініку виявлено віддалені метастази у легені - у 6 (4,7\%) чи контрлатеральну надниркову залозу - у 2 (1,6\%). Морфологічно підтверджене ураження регіонарних лімфатичних вузлів спостерігалося у $23(18,1 \%)$ хворих. У всіх випадках верифіковано світлоклітинний варіант нирково-клітинного раку в ураженій пухлиною нирці та імплантаційному венозному тромбі.

Розподіл хворих за рівнями поширення пухлинного венозного тромбу у НПВ і ураженої пухлиною нирки представлений у таблиці 1 . 
Розподіл хворих за рівнями поширення пухлинного тромбу в НПВ та ураженою пухлиною ниркою

\begin{tabular}{|l|c|c|c|c|c|c|}
\hline \multirow{2}{*}{$\begin{array}{l}\text { Рівень поширення } \\
\text { тромбу в НПВ }\end{array}$} & \multicolumn{2}{|c|}{ Права нирка $(\mathrm{n}=85)$} & \multicolumn{2}{|c|}{ Ліва нирка $(\mathrm{n}=42)$} & \multicolumn{2}{|c|}{ Всього $(\mathrm{n}=127)$} \\
\hline 0 рівень & абс. & $\%$ & абс. & $\%$ & абс. & $\%$ \\
\hline I рівень & 36 & 42,4 & 14 & 33,3 & 50 & 39,4 \\
\hline II рівень & 11 & 12,9 & 15 & 35,7 & 26 & 20,5 \\
\hline III рівень & 18 & 21,2 & 9 & 21,4 & 27 & 21,2 \\
\hline IV рівень & 15 & 17,6 & 3 & 7,1 & 18 & 14,2 \\
\hline
\end{tabular}

Частіше пухлинний тромбоз НПВ ми спостерігали при ураженні пухлиною правої нирки, ніж лівої (66,9\% проти 33,1\%, Р<0,05, відповідно). У 77 (60,6 \%) пацієнтів пухлинний тромб поширювався на різні рівні НПВ, причому у 6 $(7,8 \%) з$ них він досягав правого передсердя. У той же час, поширення пухлинного тромбу лише по нирковій вені було діагностовано у 50 (39,4 \%) хворих. У 9 (7,1\%) пацієнтів, окрім пу- хлинного тромбозу, НПВ було діагностовано флеботромбоз стегново-клубово-кавального сегменту.

Симптоми захворювання вивчали за такими групами: відсутність симптомів, симптоми локальні чи місцевого поширення пухлини (класична тріада симптомів раку нирки), симптоми ракової інтоксикації, симптоми здавлення чи порушення прохідності НПВ (табл. 2).

Таблиця 2

Характеристика симптомів у хворих НКР, ускладненим імплантаційним тромбозом ниркової та нижньої порожнистої вен

\begin{tabular}{|l|c|c|}
\hline \multicolumn{1}{|c|}{ Симптоми } & Абс. & $\%$ \\
\hline Відсутні & 32 & 25,2 \\
\hline $\begin{array}{l}\text { Біль у поперековій ділянці чи } \\
\text { животі }\end{array}$ & 57 & 44,9 \\
\hline Макрогематурія & 43 & 33,9 \\
\hline Пухлина, яка пальпується & 13 & 10,2 \\
\hline Схуднення & 10 & 7,9 \\
\hline Загальна слабкість & 29 & 22,8 \\
\hline Підвищення температури тіла & 5 & 3,9 \\
\hline Ядуха та, & 3,8 \\
\hline Підвищення артеріального тиску & 4 & 0,8 \\
\hline Варікоцеле у чоловіків & 1 & - \\
\hline $\begin{array}{l}\text { Голова медузи чи розширення } \\
\text { вен на передній черевній стінці }\end{array}$ & 0 & $-/ 7,1 * *$ \\
\hline $\begin{array}{l}\text { Набряк нижніх кінцівок (збіль- } \\
\text { шення об'єму нижніх кінцівок) }\end{array}$ & $0^{* / 9 * *}$ & $-/ 4,7^{* *}$ \\
\hline Ціаноз шкіри нижніх кінцівок & $0 * / 6^{* *}$ & \\
\hline
\end{tabular}

Примітка:

* - пацієнти 3 пухлинним венозним тромбозом;
** - пацієнти з поєднаним пухлинним та справжнім венозним тромбозом.

Клінічні симптоми було виявлено у 95 (74,8\%) пацієнтів, у той час як у $32(25,2 \%)$ хворих будьякі симптоми захворювання були відсутні. У групи пацієнтів з відсутніми симптомами наявність пухлини нирки та пухлинного венозного тромбу була випадковою знахідкою під час ультразвукового обстеження чи комп'ютерної томографії з приводу інших захворювань.

Найбільш частими симптомами були клінічні прояви місцевого поширення пухлини у вигляді болю у поперековій ділянці чи животі $(44,9 \%)$ та макрогематурії (33,9\%). Біль мав прояв різного характеру: від помірного, тупого до інтенсивного, що супроводжувався іррадіацією в стегно, пахвинну ділянку, а іноді, перебігав за типом ниркової кольки. Гематурія перебігала у вигляді інтенсивної макрогематурії і у переважної більшості пацієнтів $(74,4 \%)$ 3 цим симптомом мала одноразовий, безболісний характер. У 14\% випадків гематурія з'являлася повторно через різні проміжки часу (від 6 до 14 місяців) від першого епізоду, і лише у $11,6 \%$ спостережень мала профузний характер і супроводжувалась утворенням просторих згортків у сечовому міхурі.

Серед системних ознак ракової інтоксикації переважала загальна слабкість, що було виявлено у $22,8 \%$ випадків. 
Симптоми здавлення чи порушення прохідності НПВ у вигляді правобічного варікоцеле були зафіксовані лише в одного $(0,8 \%)$ пацієнта 3 імплантаційним тромбозом НПВ. Набряк нижніх кінцівок (збільшення об'єму нижніх кінцівок при різниці окілу гомілок чи стегна більше, ніж 3 см) діагностовано у 9 (7,1\%) хворих, у 6 з яких виявлено ціаноз шкіри нижніх кінцівок. Це були пацієнти, які окрім пухлинного тромбозу НПВ мали супутню патологію у вигляді флеботромбозу стегново-клубово-кавального сегменту, чим і була викликана поява вищевказаних симптомів.

На основі аналізу клінічних проявів та часу звернення пацієнтів за медичною допомогою, можна зробити висновок, що тривалість захворювання від моменту перших симптомів до госпіталізації у високоспеціалізований лікувальний заклад становить від 10 днів до 16 місяців (переважно на користь більш пізніх термінів звертання за допомогою). У свою чергу, хворі з безсимптомним захворюванням швидше реагують на результат випадкової знахідки під час ультразвукового обстеження чи комп'ютерної томографії у вигляді пухлини нирки, i звертаються за медичною допомогою у коротші терміни - від 7 днів до 2 місяців, лише в одиничних випадках у термін понад 12 місяців.

Клінічна картина НКР суттєво змінилась за останні десятиріччя. Класична тріада симптомів, яка була беззаперечним загальновизнаним діагностичним компонентом раку нирки, на сьогодні трапляється все рідше і в загальному не перевищує 25 \% [6]. Майже у 50\% випадків рак нирки діагностується як випадкова знахідка під час загальних апаратних обстежень 3 приводу будь-якої патології. Дана тенденція стає типовою і для випадків НКР, який ускладнений імплантаційним тромбозом НПВ.

Як продемонструвало наше дослідження, специфічні симптоми блокади НПВ трапляються рідко. Лише в одному випадку ми діагностували правобічне варікоцеле як результат пухлинного тромбозу НПВ. Однак під час виконання каватромбектомії та нефректомії ми спостерігали інтраопераційно у кожного хворого виражену венозну мережу судин, які забезпечували функціонування колатерального кровообігу. Таким чином, внутрішній колатеральний кровообіг розвивається у всіх хворих 3 імплантаційним тромбозом НПВ при НКР, що не можна зауважити стосовно поверхневого (зовнішнього) колатерального кровообігу.

За даними дослідників, які працюють над вивченням проблеми пухлинного тромбозу НПВ при раку нирки, частота клінічних проявів блоку НПВ трапляється у 6-53\% випадків $[4,8,9]$. Проте, слід зауважити, що висока частота виявлених клінічних проявів імплантаційної обструкції НПВ у дослідженні М.И. Давыдов і співавт. [9] зумовлена тим, що обстежувалась селективна група пацієнтів 3 масивною пухлинною інвазією НПВ. Цією ж гру- пою дослідників було вказано на найбільш частий симптом оклюзії НПВ - ілеофеморальний тромбоз, який вони діагностували у 22,4\% пацієнтів. Серед інших симптомів виявлено розширені венозні колатералі передньої черевної стінки $(8,2 \%)$, гепатомегалію $(8,2 \%)$, асцит $(6,1 \%)$ та ознаки тромбоемболії дрібних гілок легеневої артерії (8,2\%).

У групі наших пацієнтів поєднаний флеботромбоз стегново-клубово-кавального сегменту виявлено у 7,1\% випадків, але ми не вважаємо наявність даного симптому як безпосередній прояв імплантаціного тромбозу НПВ. Будь-яких інших значущих симптомів на користь обструкції НПВ імплантаційним тромбом ми не виявили.

Синдром Budd-Chiari, який є наслідком припинення відтоку венозної крові з печінки за рахунок обструкції печінкових вен або НПВ на рівні їх безпосереднього впадіння, не $\epsilon$ характерною ознакою імплантаціного тромбозу НПВ при раку нирки, тому що ці тромби майже не порушують відтік крові від печінки. Як свідчать дані літератури, синдром Budd-Chiari розвивається найчастіше в результаті зовнішнього стиснення НПВ пухлинами 3 місцевим поширенням пухлин наднирника чи верхнього полюсу нирки [10].

На нашу думку, відсутність специфічних симптомів блокади НПВ при імплантаційному тромбозі останньої зумовлена довготривалим (хронічним) процесом формування високої обструкції НПВ, під час якого відбувається розвиток колатерального кровоплину, який компенсує порушення прохідності НПВ. Шляхи колатерального венозного кровоплину при обструкції НПВ відмінні і залежать від боку ураженої нирки.

Так, при раку правої нирки колатеральний венозний кровоплин формується за рахунок дрібних вен капсули нирки, надниркових, нижніх діафрагмових i сечовідних вен, які зазвичай не мають прямого сполучення 3 правою нирковою веною (рис. 1а). Цей венозний колектор при обструкції НПВ дренується переважно у басейн напівнепарної вени і спрямовується вздовж хребта у висхідному напрямку до іiі впадіння у систему брахіоцефальних гілок. У процес тісно задіюється вертебральна система та хребцеві сплетення. Окрім того, у басейн напівнепарної вени впадають чисельні стовбури, пов'язані з ретрокавальною системою на рівні каудального відділу НПВ, серед яких заслуговують на увагу розширені міжхребцеві гілки, що мають горизонтальний хід. За умов обструкції НПВ, колатеральні гілки розширюються, рівень тиску в них підвищується, вони стають напруженими і небезпека кровотечі при їх пораненні під час операції значно зростає.

У той же час, при ураженні раковим процесом лівої нирки, відбувається формування колатерального венозного відтоку за зовсім іншою схемою (рис. 1б). Особливої уваги заслуговує ліва гонадна вена, по якій, за нормальних умовах забезпечується до 40\% відтоку венозної кро- 
ві від лівої нирки. Вона має зв'язок з венозним сплетенням сечового міхура, лівою загальною клубовою веною, а через комунікантні вени - 3 системою непарної вени, яка доставляє кров безпосередньо у верхню порожнисту вену. Широкий відтік венозної крові може забезпечувати- ся через нижню діафрагмову вену, кровоплин якої спрямовується в піддіафрагмовий відділ НПВ. Окрім того, як і праворуч, у колатеральному венозному відтоці бере участь система вен капсули нирки, міжхребцевих і сечовідних вен.

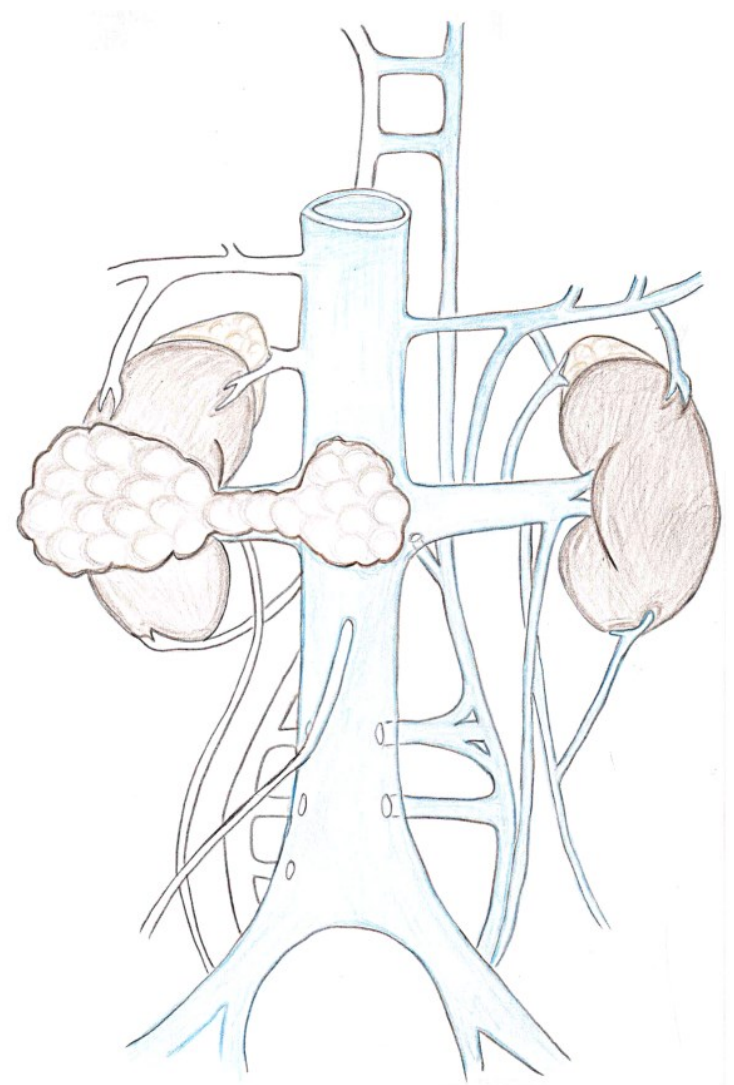

a

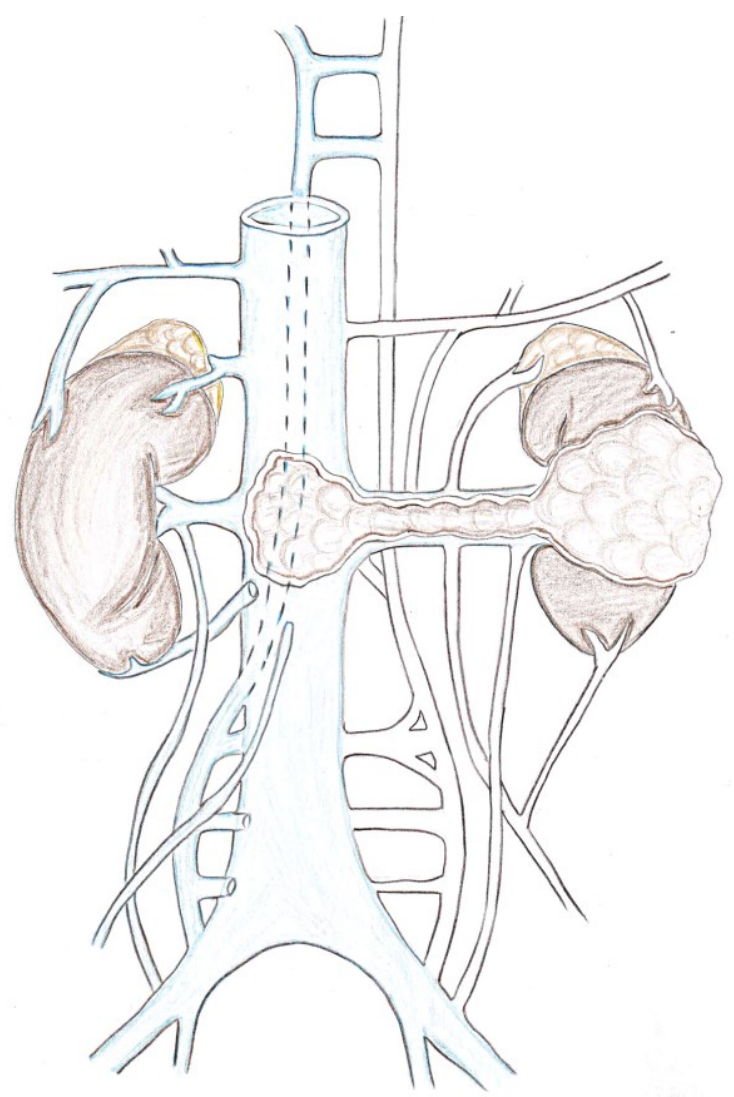

6

Рис. 1. Схема колатерального венозного відтоку: а) при раку правої нирки, ускладненому імплантаційним тромбозом НПВ; б) при раку лівої нирки, ускладненому імплантаційним тромбозом НПВ

Таким чином, навіть за нормальних фізіологічних умов кровоплин у НПВ розвантажується за рахунок паралельно функціонуючих систем сплетень хрета, непарної та напівнепарної вен, що в загальному формує кава-кавальні зв'язки. Компенсаторні можливості усіх цих шляхів настільки значущі, що можуть повністю взяти на себе функцію дистального відділу НПВ, у зв'язку з чим тромбоз цього відділу, зазвичай, не діагностується [7].

Висновки. У 25,2\% хворих на НКР, ускладнений імплантаційним тромбозом ниркової та нижньої порожнистої вен, має безсимптомний перебіг і виявлення пухлини нирки та пухлинного венозного тромбу у них $є$ випадковою знахідкою під час ультразвукового обстеження чи комп'ютерної томографії 3 приводу інших захворювань. У зв'язку з цим, пацієнтам з раком нирки необхідно виконувати в обов'язковому порядку ультразвукове та рентгенологічне дослідження НПВ на предмет виявлення імплантаційного тромбу. Наявність супутнього флеботромбозу стегново-клубово-кавального сегменту слід вважати не симптомом, а ускладненням імплантаційного тромбозу НПВ.

Інформація про конфлікт інтересів. Конфлікту інтересів немає.

Інформація про фінансування. Автор гарантує, що він не отримував жодних винагород у будь-якій формі, здатних вплинути на результати роботи.

Особистий внесок кожного автора у виконання роботи:

Бойко С.О. - ідея, мета, збір матеріалу дослідження, аналіз отриманих результатів, підготовка тексту статті. 


\section{Список використаної літератури}

1. Blute ML, Leibovich DC, Lohse CM, Cheville JC, Zincke H. The Mayo Clinic experience with surgical management, complications and outcome for patients with renal cell carcinoma and venous tumour thrombus. BJU Int. 2004 Jun; 94(1):33-41.

2. Davydov MI, Matveev VB. Hirurgicheskoe lechenie bol'nyh rakom pochki s opuholevym trombozom pochechnoj i nizhnej poloj veny. Onkourologija. 2005;2:8-15. [In Russian].

3. Pereverzev AS, Shhukin DV, Antonjan IM, Iljuhin JuA. Hirurgija vnutrivenoznyh opuholevyh trombov pri pochechno-kletochnom rake. Aktual'nye voprosy diagnostiki i lechenija mestno-rasprostranennogo i metastat cheskogo raka pochki, mochevogo puzyrja i predstatel'noj zhelezy: konf. onkourologov stran SNG, 6-7 aprelja 2012 g.: tezisy dokl. K., 2012:19. [In Russian].

4. Shhukin DV, Iljuhin JuA. Hirurgija opuholevyh trombov nizhnej poloj veny pri rake pochki. Belgorod:OAO "Belgorodskaja oblastnaja tipografija”.2007:196. [In Russian].

5. Parekh DJ, Cookson MS, Chapman W, Harrell F Jr, Wells N, Chang SS, et al. Renal cell carcinoma with renal vein and inferior vena caval involvelment: clinicopathological features, surgical techniques and outcomes. J Urol. 2005 Jun; 173(6): 1897-902.

6. Pereverzev AS. Hirurgija opuholej pochki i verhnih mochevyh putej: monografija. Har'kov.1997:394. [In Russian].

7. Savel'ev VS, Gologorskij VA, Kirienko AI. i dr. Flebologija: rukovodstvo dlja vrachej. Pod red. Savel'eva VS. M.:Medicina.2001:664. [In Russian].

8. Zisman A, Pantuck AJ, Chao DH, Wieder JA, Dorey F, Said JW, et al. Renal cell carcinoma with tumor thrombus: is cytoreductive nephrectomy for advanced disease associated with an increased complication rate? J Urol. 2002 Sep;168(3):962-7.

9. Davydov MI, Matveev VB, Volkova MI, Begaliev AK, Feoktistov PI, Kuznecov KP, et al. Hirurgicheskoe lechenie bol'nyh rakom pochki s massivnoj opuholevoj invaziej nizhnej poloj veny [Internet]. Onkourologija. 2017; 13(1):27-36. Available from: https:/oncourology.abvpress.ru/oncur/article/view/644/621. [In Russian]. https://doi.org/10.17650/1726-9776-2017-13-1-27-36

10. Eren S., Akdağ R. Rare complication of adrenal neuroblastoma: Budd-Chiari syndrome. Pediatr Int. 2003 Dec;45(6):737-9.

Стаття надійшла до редакції: 19.02 .2019 р. 